Czifra György, Ladislav Morovič

\title{
Mérnöki rekonstrukció és gyorsprototípusgyártás a karbantartásban
}

György Czifra - Ladislav Morovič Reverse engineering and rapid prototyping in the maintenance process

\begin{abstract}
The reverse engineering and rapid prototyping, walking hand-in-hand exactly fulfill the task for which are suitable - to help quickly construct and reconstruct the damaged components. Our goal is to find areas where the technologies are not yet widely available, or find the technologies that can be used for industrial purposes and for the everyday practice.

Keywords: CAD, CAM, reverse engineering, rapid prototyping, maintenance
\end{abstract}

\section{ÖSSZEFOGLALÓ}

A visszafejtő mérnöki tevékenység és a gyorsprototípusgyártás kéz a kézben járva pontosan betöltik azt a feladatot, amire alkalmasak - rekonstruálni és gyorsan legyártani a sérült komponenseket. Kutatásaink célja megtalálni olyan területeket, ahol a feltüntetett technológiák még nincsenek elterjedve, illetve megtalálni azokat a technológiákat, melyek ipari célokra alkalmas módon használhatók a mindennapi gyakorlatban.

Kulcsszavak: CAD, CAM, reverse engineering, rapid prototyping, maintenance

\section{BEVEZETÉS}

Sokan feltehetik a jogos kérdést, hogy kerül a csizma az asztalra, tehát, hogy hogyan függ össze egy alapvetően prototípusgyártásra és teszttermékek gyártására kitalált és alkalmas technológia a javítással, a karbantartással? A válasz egyszerű és logikus: egy tönkrement alkatrész, amelynek nincs meg a gyártási dokumentációja, amelyről nincs mérethelyes információnk a helyes múködés időszakából pótolható, ha visszafejtő, rekonstrukciós mérnöki tevékenységgel le tudjuk képezni a sérült valós alkatrészt, elkészítjük a megfelelő számítógépes modellt, újraalkotjuk immáron a korrekt, beépítésre alkalmas komponenst, legyártjuk és beszereljük.

Cikkünk elemzi a fenti módszer lehetőségeit, rávilágít az esetleges problémákra és keresi megoldásukat. Munkánk során sok területet megvizsgáltunk és elemeztünk, ebben a cikkben csak néhány fontosabb, érdekesebb megoldást emeltünk ki.

\section{A MÓDSZER LÉNYEGE}

Valójában a bevezetőben említett folyamat mindenki számára ismert, aki foglalkozik a térbeli képalkotással, illetve a tárgyak, ebben az esetben gépalkatrészek számítógépes modelljének kialakításával. A gyakorlat rengeteg eljárást ismer, amelyek többé-kevésbé kielégítik az elméleti kutatások igényeit - tiszta, pormentes laboratóriumi körülmények között, ám gondban lehetünk, ha valós, üzemi környezetben kell alkalmazni ezeket a modellgeneráló eljárásokat. A legnagyobb problémát nyilván a roncsolt alkatrész megfelelő tisztítása okozza, hiszen a szennyeződések erősen befolyásolják a digitalizálás pontosságát. Természetesen figyelembe kell vennünk, hogy milyen eljárással állapítjuk meg a modell kialakításához elengedhetetlen pontfelhő egyes pontjainak koordinátáit. 
A kizárólag optikai elven múködő rendszerek, mint a GOM: ATOS típus érzékeny a felületen található szennyeződések által okozott mérethibákra, hiszen múködési elvét tekintve a háromszögelési módszert alkalmazza: az egység nagyon pontos csíkmintát vetít ki a mérendő tárgyra, amelyet két kamera rögzít. Optikai transzformáció segítségével, a Gauss féle eloszlást is figyelembe véve, valamennyi képpont térbeli koordinátáit ki lehet számítani. A számítás eredménye egy pontfelhő, amelyből felületi háló generálható. Ez egy poligonháló, amely a rendszerből exportálható olyan formátumban, amely lehetővé teszi további CAD rendszerek alkalmazásával előbb felületmodell, továbbá térfogatmodell kialakítását.

A fentiekben csak egy példát mutattunk be, nyilván az összes optikai rendszer, tehát ahol nincs fizikai kapcsolat a mérendő alkatrész és a mérőberendezés között ebben a tekintetben sebezhetőnek bizonyul. A sérült, roncsolt alkatrész tisztítása tehát az első kulcsfontosságú tényező.

Amennyiben valamilyen mérőcsúcssal ellátott, esetleg lézeres képalkotóval kombinált berendezés áll rendelkezésre, akkor a szennyeződések torzító hatása - emberi korrekció segítségével -kivédhető. Az egyik tipikus példája az ilyen digitalizáló berendezésnek a FARO karos lézerfejes mérőcsúcssal ellátott készülék, természetesen a megfelelő támogató háttérprogrammal együtt. Sajnos cikkünk terjedelme nem engedi meg, hogy részleteiben ismertessük ezt a rendkívül progresszív technikai megoldást, felhasználása nagyon széles körben megvalósul könnyú kezelhetősége, hordozhatósága következményeként.

A térbeli szerkezetek digitalizálásának egyik fontos felhasználási területe a nagy kiterjedésű, bonyolult üregezésű objektumok - mint például a hajók. A hajók géptermének beépítése nem egyszerű feladat, több előző cikkünk is foglalkozik a témával. Az egyik sarkalatos pont az objektum matematikai modelljének összehasonlítása a valós, felépült acélszerkezet geometriájával.

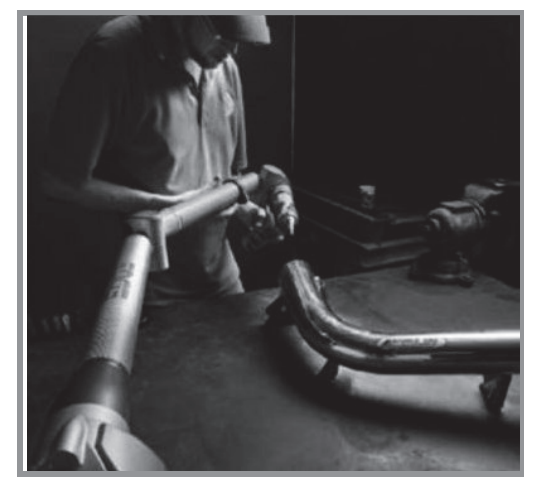

1. ábra: FARO letapogató csőgyártás közben [2.]

$\mathrm{Az}$ összehasonlítás nagy hatékonysággal végezhető, ha sikerül pontos letapogatással megfelelő pontfelhőt leolvasnunk, ebből megfelelő eljárással felületmodellt állítunk elő, majd ezt a modellt összevetjük a CAD rendszerben elkészült térbeli modellel. Az ilyen eljárás segítségével nagyszerűen kiszűrhetők a pontatlanságok és meg lehet változtatni a beépítendő komponensek - ebben az esetben a csőágak -méretét, geometriáját még a beszerelés fázisa előtt, így elkerülhetők a helyszíni átalakítással járó többletköltségek, vagy a selejtek kialakulása.

A karbantartás és javítás egy hajó külhéja esetében nagyon bonyolult és technológiailag igényes feladat. A külhéj geometriája általában sablonok segítségével készül $s$ mivel meg kell felelnie az áramlástan alaptörvényeinek - az úszással szemben a lehető legkisebb ellenállást szabad kifejtenie - ezért egy esetleges sérülés esetén rendkívül fontos a pontos geometria betartása, a javított rész szinte varratmentes illesztése az eredeti ép felülethez. Ezt a munkát hatékonnyá és nagyságrendileg pontosabbá lehet tenni a térbeli képalkotó berendezések segítségével. A megfelelő alappontok felvétele után megtörténik a felület digitalizálása, a pontfelhő kialakítása, a poligonháló kifeszítése az alappontokra, a felület újragenerálása, sablonok gyártásához szükséges formák kialakítása, sablonok legyártása, a külhéj ráfeszítése a sablonokra, majd a folt felhelyezése a sérült felület helyére. 
Az alábbi ábrákon éppen egy ilyen felmérés folyik.

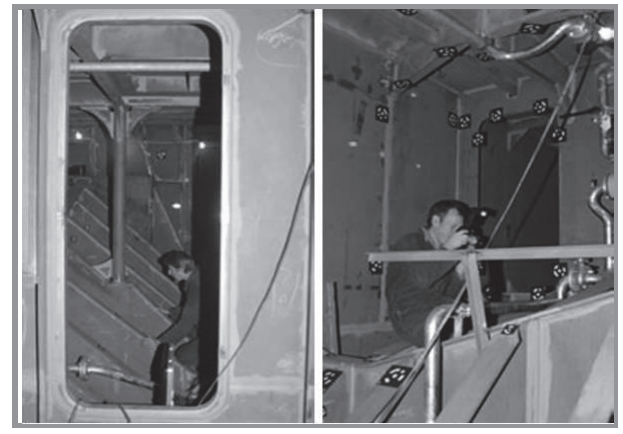

2. ábra: Sarokpontok meghatározása hajótestben [3.]

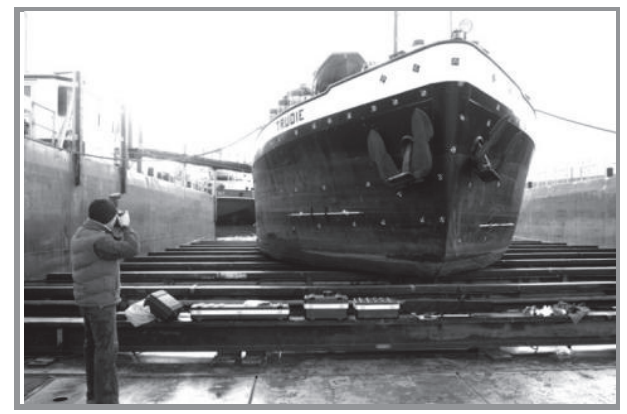

3. ábra: Sarokpontok meghatározása hajó
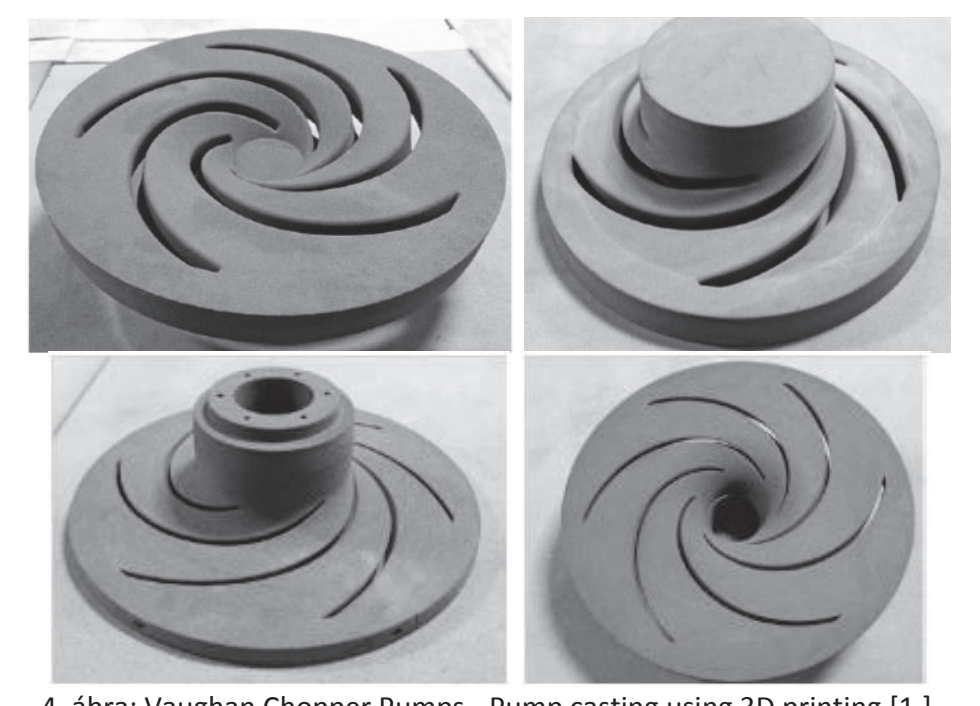

4. ábra: Vaughan Chopper Pumps - Pump casting using 3D printing [1.]

\section{külhéján [3.]}

A javításban történő felhasználás rendkívül szép példájaként a centrifugális szivattyúk járókerekének rekonstrukcióját, valamint a turbinalapátok pótlását szeretném megemlíteni.

Különös jelentőséggel bírnak az olyan szivattyúk felújítási eljárásai, melyek dokumentációja nem áll rendelkezésre, illetve nagyon gyorsan kell megoldani a javítás problémáját.

Ebben az esetben is a térbeli letapogatási képalkotási technológia áll rendelkezésünkre. A pótló alkatrész legyártására viszont - és itt lép be a képbe a gyorsprototípusgyártás -megvan a megfelelő technológiánk. A különféle műanyagokkal dolgozó nyomtatókkal most nem szeretnénk foglalkozni, forduljunk az úgynevezett lézerszinterézis felé. $A z$ úgynevezett SLS - szelektív lézer szinterézis múködési elve ismert, ám a rendelkezésre álló ma felhasználható alapanyagok lehetóvé teszik nemcsak formák, szerszámok, hanem munkadarabok - értsd pótolandó alkotóelemek gyártását is.

Végezetül egy gyakorlati példát szeretnék bemutatni: egy szivattyú járókerekének öntőformáját 3D nyomtatóval nyomtatták ki - a forma speciális homok és kötőanyag keveréke. 
Czifra György - Ladislav Morovič: Mérnöki rekonstrukció és gyorsprototípusgyártás ...

\section{3. ÖSSZEFOGLALÁS}

Mint az a fentiekből kitűnik, a visszafejtő mérnöki tevékenység és gyorsprototípusgyártás kéz a kézben járva pontosan betöltik azt a feladatot, amire alkalmasak - rekonstruálni és gyorsan legyártani a sérült komponenseket. Kutatásaink célja megtalálni olyan területeket, ahol a feltüntetett technológiák még nincsenek elterjedve, illetve megtalálni azokat a technológiákat, melyek ipari célokra alkalmas módon használhatók a mindennapi gyakorlatban.

A fenti megoldások és módszerek kutatása Szlovák Múszaki Egyetem projekt 1746 Vybudovanie multimediálnej učebne címú kutatási - fejlesztési projektje keretén belül lettek megvalósítva.

\section{IRODALMI HIVATKOZÁSOK}

[1.] http://www.chopperpumps.com/company.html, 2014-03-19

[2.] http://www.faro.com/home, 2014-03-19

[3.] http://www.gom.com, 2014-03-19 